\title{
THE BANK'S IMAGE: FORMATION AND WAYS OF IMPROVEMENT
}

\section{Stela Ciobu}

Academy of Economic Studies of Moldova, Chisinau, Rep. Moldova

\section{Victoria Iordachi}

National Institute for Economic Research, Chisinau, Rep. Moldova

\section{Olesea Efimenco}

Academy of Economic Studies of Moldova, Chisinau, Rep. Moldova

CMESTE

JEL Category: G21, G41

\begin{abstract}
The bank's image is the totality of perceptions, opinions, and visions of different contact groups about a bank. Its study allows determining the level of bank trustworthiness, on which depends its ability to attract financial resources and, therefore, to perform its activity. Due to this fact, image is a highly important asset for a bank. The assessment of bank image differs from one group of interest to another. It determines the division of the aggregate bank image into elements, namely: business image, social image, an image in the financial sector, image made by clients, by the government, by the international public, etc. Therefore, the formation and management of the bank image is a complex of activities, which include: communication of the corporate identity using different marketing techniques, correct management of the bank, especially related to risks and prudential norms, qualitative banking products, and high level of customer service. The recommended method for improving the image of a bank contains the following steps: evaluation of the current image; reviewing the philosophy on which the bank's activity is based and, if necessary, its re-formulation; checking the consistency between the bank's mission, objectives and long-term strategy; improving the elements of external and internal images, and developing the undiscernible banking image by establishing deeply subconscious links between the bank's image and the emotions and values of the general public.
\end{abstract}

Keywords: bank's image, reputation, corporate identity, advertising, management of bank's image, banking sector.

\section{INTRODUCTION}

Actuality. The financial sector is characterized by a high level of competition. To ensure its

Address of the corresponding author: lordachi Victoria 莑:timush_v@yahoo.co.uk competitive advantages and continuity in its activity, the bank should prove that it is a reliable and trustworthy institution. In this regard, the bank's image management should be a domain of 
keen interest for every bank, because it directly impacts the accessibility of the bank to financial resources and, therefore, its market share. But to perform appropriately this management, there should be a clear understanding of what bank image is, what elements it consists of, and how it is created.

The goal of this research is to reveal the importance of the image for a banking institution and to propose measures, which can be undertaken to improve the bank's image. The objectives, established for the achievement of the set goal include:

- defining the concept of bank image and its main elements;

- determining the way the bank image is formed;

- a suggestion of solutions in the improvement of the bank's image.

The research methodology is based on the deductive method, comprising the documentary and graphic methods. Under the documentary, the method is performed in the study of bibliography sources, linked to the research problem, such as specialty literature, research papers, publications, etc. Some of the findings were further presented in graphical form.

\section{CONCEPT AND ELEMENTS OF THE BANK'S IMAGE}

The financial market is characterized by a high level of volatility (Nitu, 2000), due to the existence of a large number of factors, which determine its activity and development. In such a continually changing environment, the banks are aware that in their aim to obtain profit, their exposure to risk is permanent. The consideration of all risks related to the banking activity should be performed in a prudential manner, taking into account not only the regulations imposed by the central bank, desired profit level, or eventual losses, but also the possible effects on both external and internal image of the bank (Nitu, 2000).

But what is a bank image? Generally, the corporate image is the totality of perceptions, opinions, and visions of different contact groups about a company. It represents an instrument, created for achieving the company's strategic goals (Burtseva \& Mironova, 2008). A well-created image will influence the public/ client to act in a certain way towards the image holder (Gorchakova, 2005). Thus, image is an essential element for any corporation, which enters the market and is concerned about the way its products are perceived by the public. Image is paramount for the companies in the financial and banking sector, in which the relationships are based mainly on trust (Rogacheva, 2007).

Bank image assesses qualitatively the opinion of the general public about the bank's activity, taking into consideration also the activity of its shareholders, their affiliated persons, dependent, and daughter-companies (Smirnova, 2009). Additionally, the image can be perceived as an objective result of the bank's activity on the market, generated by the coincidence between the bank's interest and the interest of the public and clientele (Reshetikova, 2009).

The image of a bank can be seen from three perspectives (Reshetikova, 2009):

1. the intentionally created representation, the scope of which is to impact emotionally and psychologically the recipients of information with the aim of advertising.

2. the fixed opinion of the customers, partners, and the general public about the prestige of the bank, quality of its products or services, reputation of its management.

3. a complex system of visual identification, which facilitates the establishment of a favorable organizational style and amplifies the advertising impact on clients, increases the partners' trust and contributes to the improvement of the market position of the bank.

The bank's image includes the following features (Smirnova, 2009):

- there exist two parties: the inductor, source of information (bank), and the recipient receiving the respective information (e. g. public).

- is presented as being the information about the bank, fixed in a symbol or message.

- image, like information, is communicated during the "dialogue" between the bank and its "audience".

- image is not always the representation of the real characteristics and possibilities of the bank but can be perceived as such. 
- it can influence and manipulate the behavior of the recipients of the information towards its inductor, the bank.

- is characterized by individuality, due to its formation in specific, conditions under the influence of different factors (Solcan, 2003).

The public appreciates how successful is the activity of a bank. From the perspective of different groups of interest, the image of the same bank differs, due to the distinction in parameters that affect the bank's perception (Rogaleva, 2007). This fact determines the elements of the bank image, presented in figure 1. For customers, for example, are important the quality and diversity of bank products and services and the corporate identity of the bank. Partners would value more the

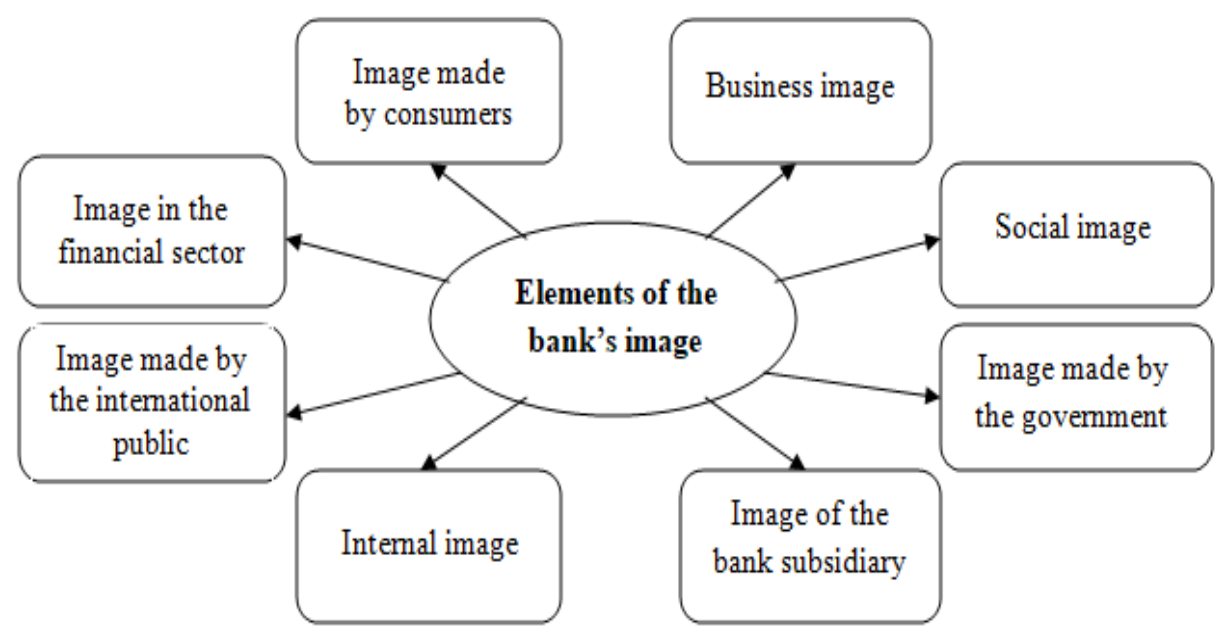

Figure 1 Elements of the bank's

Source: Adapted by authors based on Burtseva \& Mironova (2008)

A positive bank image is a strategic resource, which helps the bank to adapt to the market conditions, being in such a way a tool for its survival and development (Reshetikova, 2009). Also, it ignites the desire of potential clients to deal with the bank. Because the trustworthiness is the ground of financial relations between a bank and a client, the latter would choose the bank with a better image. The positive image kept over time is of great importance for a bank, because it offers numerous advantages (Rid, 2008):

1. capturing the attention of potential clients, partners, investors, and workers. It offers the opportunity to be the first option for those who are seeking a commercial or partnership relation. volume of bank operations and the style of doing business. The society will look at the sponsorship activities, performed by the bank, its support, and help in solving social problems. The level of customer service influences the image of the bank subsidiaries. The internal image would be surely affected by the corporate climate, working conditions, and social benefits of the workers. For the government of particular importance is the implication of the bank in the regional social programs and the good faith of the bank's activity. The volume of operations, trustworthiness, and financial stability is of high importance for the financial sector. And the international community takes into consideration the professionalism of personnel and the respect of ethical standards in doing business.

2. reduction of the expenses for advertising, because a good image promotes the bank's products and services by itself.

3. increase in bank's revenues. The positive image proves that there exists trust from the clients towards the bank, which, respectively, contributes to the increase in the value of bank operations, and therefore finds its reflection in the revenues of the bank (Akulich, 2013).

4. consolidation of the bank's position on the financial and capital markets. Through the correct development of the bank image and appropriate management of the bank activity, is gained the appreciation in the stock price of the bank's shares and improves the reputation of the bank in the financial sector. 
5. serves as a motivational tool for the personnel. As mentioned previously, the potential workers also draw their attention to the image of the bank in which they intend to work. Therefore, a positive image attracts by itself new human resources and, also, allows keeping the existing qualified workers.

6. serves as a strategic asset in times of uncertainty for the bank. When the bank faces a problem, related to the launch of new products or faults in the day-to-day activity, which can impact negatively the performance indicators of the bank, the values imparted by the bank image among its personnel and the clients' appreciation of the activity before the crisis, can serve as a point of return for the bank to the past level of main financial indicators, helping, in such a way, to overcome the uncertainty.

7. represents a strong competitive advantage. A good image helps to attract more clients, respectively, more financial resources and increase the market share as compared to the existing competitors. It also protects the bank when the market is entered by new participants.

\section{Table 1. Types of bank's image}

\begin{tabular}{|l|l|}
\hline $\begin{array}{c}\text { Type of } \\
\text { image }\end{array}$ & \multicolumn{1}{|c|}{ Characteristic } \\
\hline Tangible & $\begin{array}{l}\text { represents the first impression of the } \\
\text { bank }\end{array}$ \\
\hline Intangible & $\begin{array}{l}\text { is linked with the response reaction of } \\
\text { the consumers of the banking } \\
\text { products to the changes in customer } \\
\text { service and the changes in the attitude } \\
\text { of the personnel towards the bank }\end{array}$ \\
\hline Internal & $\begin{array}{l}\text { ensures the working climate, reflects } \\
\text { the attitude of the personnel towards } \\
\text { the policy promoted by the } \\
\text { management and the bank itself }\end{array}$ \\
\hline External & $\begin{array}{l}\text { depends on the internal image and the } \\
\text { attitude of the general public towards } \\
\text { the bank }\end{array}$ \\
\hline
\end{tabular}

Source: Authors based on (Akulich, 2013)

The bank image also reveals the comparison between the promised functionality of the bank products, expressed in the advertising and product description, and actual functionality, along with the emotional feelings of the client during his collaboration with the bank (Akulich, 2013). Meeting consumer expectations is paramount in building customer loyalty. The last depends on the subjective evaluation of the bank by the consumers. While this evaluation has a psychological aspect, for a better understanding of what the bank image is, it can be divided into 4 subcategories, which are presented in table 1.

Internal bank image is based on the psychological aspects of the personnel's attitude towards the bank. A positive internal image serves as a means of self-regulation and self-motivation (Gorchakova, 2005). It fosters the staff confidence in the security at work, which serves as a driver for the personnel to work with greater effort and to look for the continuous professional development and improvement of their qualification (Akulich, 2013). All these contribute to the formation of a positive impression about the bank as a professional, reliable market participant, and employer. Additionally, the bank personnel ensures the accurate informational channel between the bank and the existent and potential clients. The last can "feel" the internal image of the bank, and it can affect the desire of the clients to enter the bank, and therefore, its performance and competitiveness. In such a way, the internal image plays a paramount role in establishing the positive external image of the bank.

The external image includes the presentation of the bank as a responsible business partner, which offers quality products and services, the activity of which is based on the social and corporate techniques, such as (Reshetikova, 2009): environment protection; social security of employees; development and creation of the new workplaces; pension, educational, medical, cultural, housing and other types of programs, which have social and economic importance for the society, country and national economy as a whole; and management of human resources. The visual features, which fix the information about the interior and exterior of the bank subsidiaries and agencies, as long as the exterior appearance of the bank personnel also contribute to the building of the external image of the bank. 


\section{FORMATION OF THE BANK IMAGE}

The bank image is the totality of socio-economic and organizational relationships, oriented towards the creation of the bank's representation, its "face" (Reshetikova, 2009). The first step in establishing a positive and successful bank image is the welldeveloped corporate identity. It includes firstly the totality of the color and graphic elements along with slogans, which aim to distinct the bank from its competitors. All these symbols should ensure the visual and meaningful unification between the bank's products and services and the informational flows provided by the interior and exterior appearance of the bank (Akulich, 2013). The corporate identity should reflect the mission, structure, business activity, and assertions of the bank. Only as a result of the management of the corporate identity and the use of corporate communications appears the image (Smirnova, 2009).

An important element of corporate identity is also corporate governance. "Corporate governance is a set of relationships between a company's management, its board, its shareholders and other stakeholders which provides the structure through which the objectives of the company are set, and the means of attaining those objectives and monitoring performance. It helps define the way authority and responsibility are allocated and how corporate decisions are made" (BCBS, 2015). Therefore, the corporate governance unifies the personnel, fortifies the personnel's morale (Akulich, 2013), contributes to a better working climate, and, indirectly, leads to better customer service.

When the bank is just established and attempts to start its activity, high efforts are oriented towards a good advertising campaign, which communicates about the bank's corporate identity. The correctly chosen marketing techniques will allow the bank to reach its target audience and acquire the first clients. In such a way is created the initial bank image, which represents the aggregation of the individuals, businesses, and governmental organizations' opinions about the bank before they approach the last. The values, business standards, features, and usefulness of the products and services promoted through the popularization means of mass-media - they all create in the minds of the potential clients some expectations regarding the activity of the respective bank. But initial image changes over time after the establishment of the first relations with clients, partners, investors, and other stakeholders. The way how the current image is formed is presented in the following scheme.

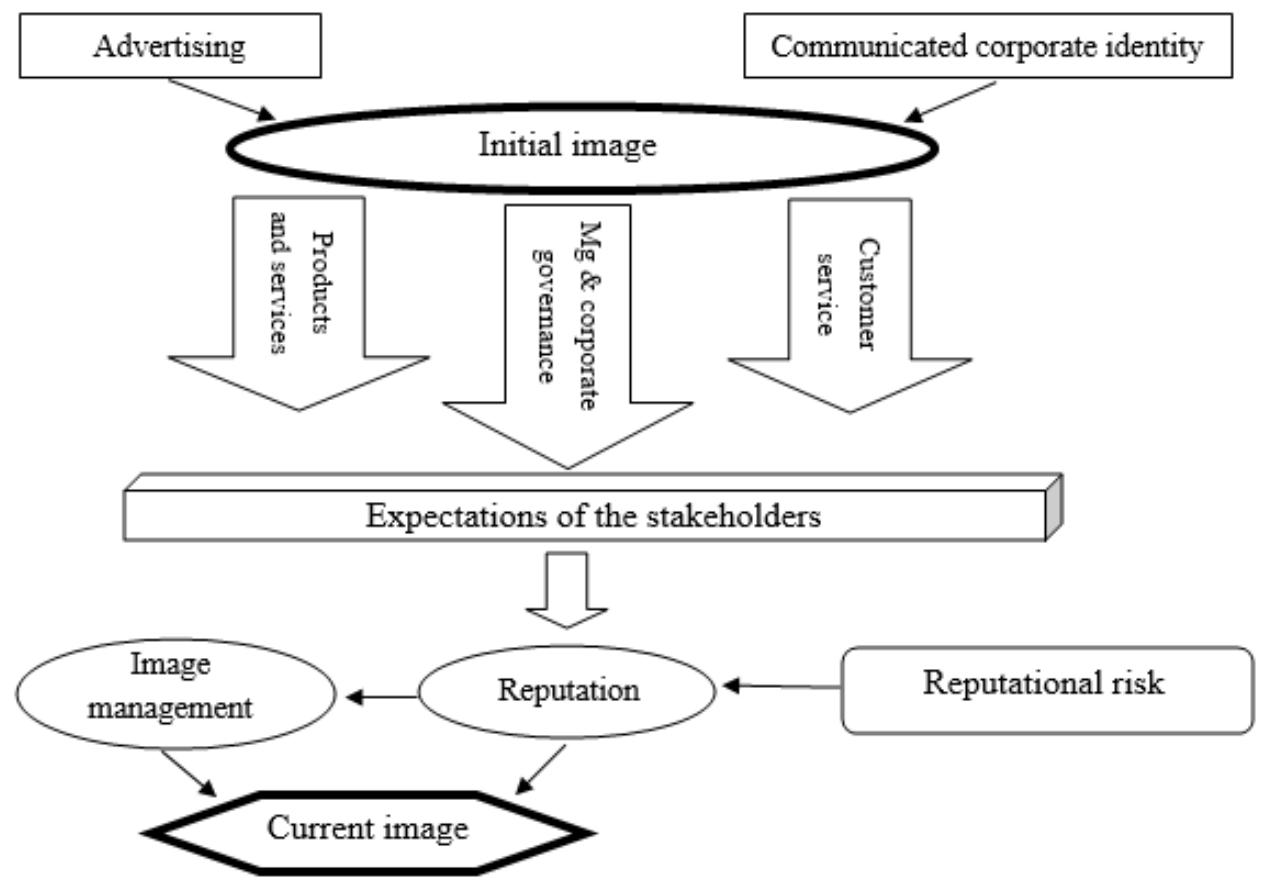

Figure 2 Formation of the bank's image (adapted by authors) 
The moment when the bank starts to attract deposits, grant credits, and offer its services to the clients - it is a crucial point in the creation of the bank's reputation. The later represents a collective assessment of a bank's attractiveness to a specific group of stakeholders as compared to its competitors and/or the established standards (Trotta \& Dell'atti, 2016). On reputation depends the bank's trustworthiness, and, thus, the number of financial resources it can further attract. The reputation is considered to be positive when the expectations of the stakeholders are met and fulfilled by the bank. For example, the clients will have positive feedback about the bank when the products and services, offered by the bank, fully satisfy their necessities and the customer service provided by the bank's personnel is impeccable. Additionally, a good reputation appears in the situation when the bank's image and the personal system of values of the individuals coincide (Smirnova, 2009). The strong corporate governance and the ethical business activity performed by the bank will be of great importance for shareholders, regulators, and business partners. The well-performed financial intermediation function and the social advantage of the bank's products will lead to a positive assessment of the bank by the government. Therefore, the past experiences in collaboration with the bank generate impressions in the stakeholders' minds regarding the respective entity and their aggregate amount represents the bank reputation (Smirnova, 2009). This reputation affects the actual perception of the bank, consequently its current image.

The positive reputation usually generates mouthto-mouth advertising for the bank, through the recommendations made by the existent and former stakeholders to their acquaintances. In such a way, the good reputation affects positively the bank image, and, vice-versa, the negative one is capable to destroy it, unless the timely and appropriate image management decisions are taken. This is why, in the scheme, reputation influences both the image itself and its management.

Marketing channels and techniques, customer service, corporate culture, etc., which are used in image management, and the reputation - all are influencing the bank image (Rogacheva, 2004).
But the image management tools can be directly influenced by the bank, unlikely its reputation, which is the subjective judgment of each stakeholder. The bank can only do its best to ensure its stability, durability, profitability, and trustworthiness, which impacts positively the bank's reputation.

The efforts of the bank to ensure the best possible management, which will allow to respect the bank's strategy, comply with all regulations and follow the best practices in the banking industry, should orient also towards the consideration of the reputational risk. When the bank registers the occurrence of the reputational risk resulted from inappropriate risks or human resources management, deficiencies in the bank's corporate governance, inefficient marketing techniques, misuse of the bank by its clients for criminal activities, dishonest shareholders, failure to adapt on time to the new tendencies in the banking industry, etc., it immediately affects the bank reputation. The bank loses its clients, partners, investors. The negative publicity appears which in the end affects negatively the bank's image.

Because the bank products possess usually a long-life cycle, the bank's image can be considered to be one with big implications. This is why the appreciation and especially feedback from the stakeholders are of great importance for monitoring the bank's image and tanking appropriate and timely decisions for its improvement (Solcan, 2003). Therefore, the management of the bank image is a complex of activities, oriented to each factor named above.

\section{IMPROVEMENT OF THE BANK'S IMAGE}

Improvement of the bank image is especially important when the bank faces problems related to its reputation or market share. It allows the bank to retake its activity in a new ampleness. The bank image is the result of the day-to-day activity of the bank and is not created exclusively by the marketing department. Reducing the bank image only to visual characteristics is a superficial approach and it does not bring success. Acknowledgment of this fact is the first step in the improvement of the bank image. 
The process should start with the gathering of the information related to the current position of the bank within the banking sector and the assessment of the current bank image through interviewing and establishment of the focus groups. The main directions and factors to be studied during the interviewing process are presented in table 2 .

\section{Table 2 Concept of corporate image study}

\begin{tabular}{|c|c|c|c|}
\hline \multicolumn{2}{|c|}{ Type of image } & Key directions of study & Basic Factors \\
\hline \multirow{2}{*}{ 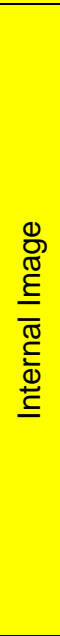 } & 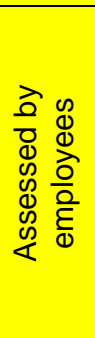 & $\begin{array}{l}\text { - Workplace satisfaction. } \\
\text { - Awareness about the general development strategy and } \\
\text { mission. } \\
\text { - Evaluation by the employees of the clients' awareness of the } \\
\text { entity. } \\
\text { - Identification of the associations related to the entity } \\
\text { - Level of company prestige. }\end{array}$ & $\begin{array}{l}\text { Personnel's loyalty; the } \\
\text { possibility of career } \\
\text { growth; a system of } \\
\text { moral and material } \\
\text { remuneration; social and } \\
\text { psychological climate. }\end{array}$ \\
\hline & 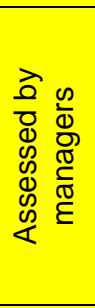 & $\begin{array}{l}\text { - Assessment of the employees' workplace satisfaction. } \\
\text { - Specification of the general development strategy and mission. } \\
\text { - Evaluation by the managers of the clients' awareness of the } \\
\text { entity. } \\
\text { - Identification of the associations related to the entity } \\
\text { - Level of company prestige. }\end{array}$ & $\begin{array}{l}\text { Managers' loyalty } \\
\text { towards the employees; } \\
\text { possibilities of the } \\
\text { employees' professional } \\
\text { growth; social and } \\
\text { psychological climate. }\end{array}$ \\
\hline \multirow{2}{*}{ 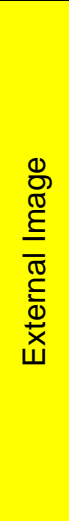 } & 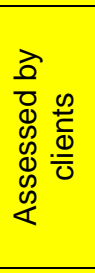 & $\begin{array}{l}\text { - Evaluation of the company's prestige and trustworthiness. } \\
\text { - Informational transparency. } \\
\text { - Perception of the mission and development strategy. } \\
\text { - Identification of the associations regarding the company. } \\
\text { - Corporate identity of the company. }\end{array}$ & $\begin{array}{l}\text { Degree of loyalty; quality } \\
\text { and features of products, } \\
\text { services, and customer } \\
\text { service; prices, bonuses, } \\
\text { and discount systems. }\end{array}$ \\
\hline & 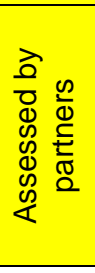 & $\begin{array}{l}\text { - Evaluation of the company's prestige and trustworthiness. } \\
\text { - Informational transparency. } \\
\text { - Perception of the mission and development strategy. } \\
\text { - Identification of the associations regarding the company. } \\
\text { - Corporate identity of the company. }\end{array}$ & $\begin{array}{l}\text { Evaluation of the quality } \\
\text { of collaboration; the level } \\
\text { of satisfaction resulted } \\
\text { from the partnership. }\end{array}$ \\
\hline
\end{tabular}

Source: (Bushuyeva \& Frolova, 2015).

During the banking, sector study are undertaken the following actions (Bushuyeva, \& Frolova, 2015): determination of the degree of competitiveness; identification of the main competitors and assessment of the advantages and disadvantages of the bank as compared to them; determination of the range of offered banking products; detection of the attitudes towards each participant in the banking sector; determination of the "portrait" of the target clients' segment of the bank; determination of the satisfaction level of the existent clients, their expectations and degree of loyalty towards the bank and positioning of the bank in the market and

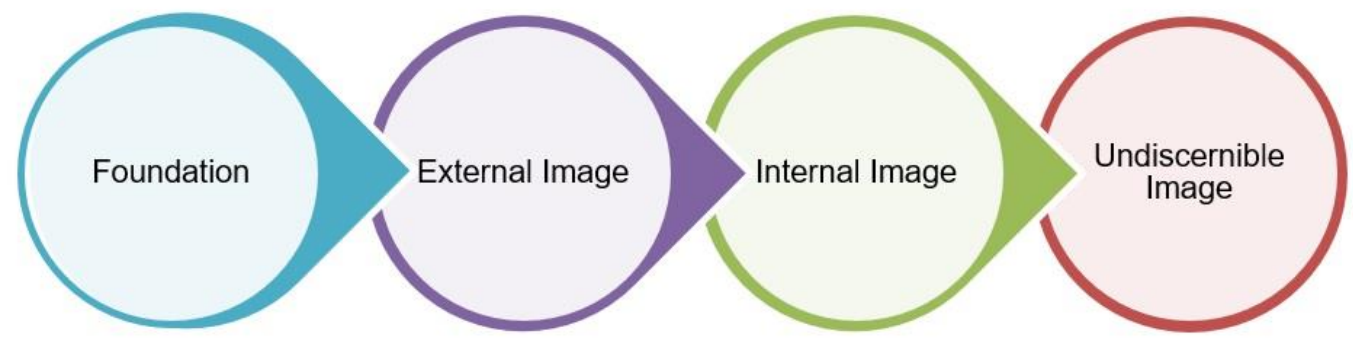

Figure 3 The strategic plan of the image improvement (adapted by authors, based on Garstea, S.,2002) 
the perception of the target segment. The performance of such a complex study allows determining the strong and weak points in the actual bank image among its stakeholders. The detected deficiencies should be further eliminated through changes in image management strategy. Further, the management of the bank's image should run through four stages, specified in figure 3. The effects of the correct process of foundation can result in high morality, sound corporate culture, and governance within the bank. All these will ensure the efficient segregation of responsibilities among the bank's employees and the effective day-to-day activity of the bank (Garstea, 2002). At this stage is also justified the importance of the bank from a social point of view and is created of the premises for the next step external image management.

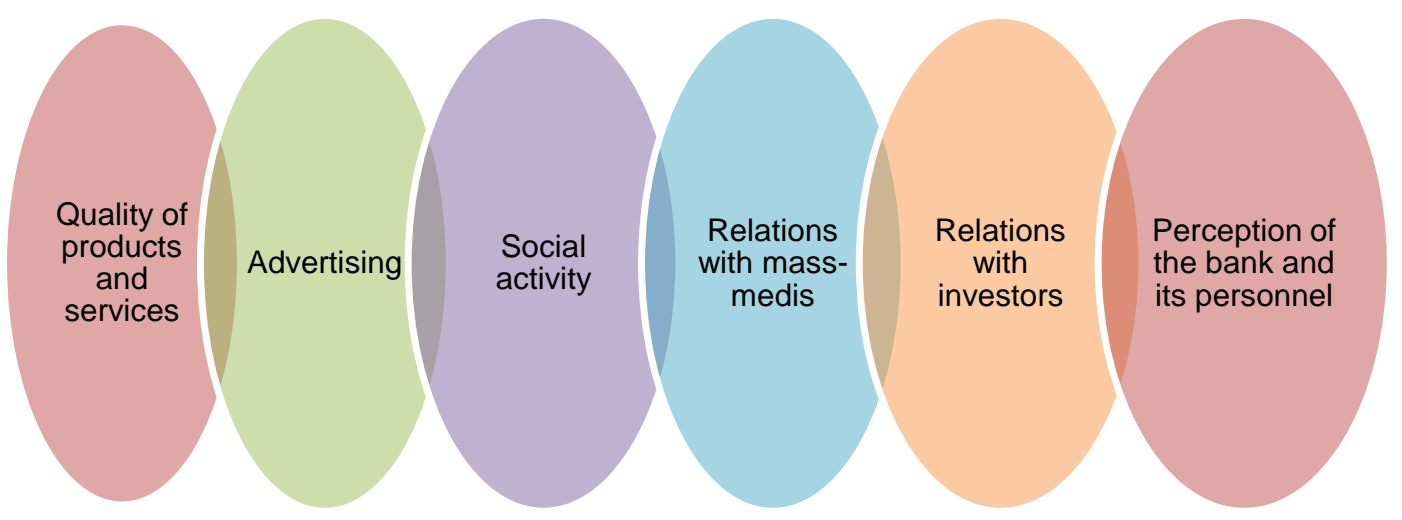

Fig. 4 Elements of external image management (adapted by authors, based on Garstea, 2002)

The quality of banking products and services depends on customer satisfaction and loyalty. Thus, the products and services should be designed to meet the clients' expectations and should contribute to the formation of the bank's reputation, which together with advertising increase the prestige and popularity of the bank. Advertising on its turn should have an emotional impact on the target clients' segment of the bank in such a way affecting unconsciously the audience's behavior (Garstea, 2002). Important to be mentioned is the fact that advertising impacts faster the bank's image in a positive way when the bank is involved in and supports different social projects (Rogacheva, 2004). The activities of social responsibility bring not only necessary resources for a good cause, but also help to establish emotional relationships between the bank and society (Garstea, 2002). The positive image is gained also by the targeted marketing communications through mass media. For big banks, for example, is essential the work with mass media (Burtseva \& Mironova, 2008), because it increases the prestige of the bank, highlights its strong points and serves as an intermediary between the bank and potential clients, who seek for the products and services, the bank is offering (Rogacheva, 2004).

Bank image is one of the factors which influence the bank's capacity to attract investors. To be perceived as a stable and reliable business to invest money in, the bank management should ensure the fruitful collaboration with the existent shareholders, based on transparency and performance.

When the bank wants to create its image, it should decide firstly, what impression it wants to be made about the bank (Rogacheva, 2004). In this regard, the bank management should focus on the visual attributes, such as name, logo, slogan, employees' dress code, the interior and exterior design of the bank's subdivisions, their territorial footprint, etc. Each component should be well designed, spreading the bank's philosophy and corporate identity.

The interior image of the bank is linked to the programs aimed to boost the workplace satisfaction of employees, their trust towards the bank as a sound and reliable employer, and their motivation to work professionally and efficiently, fulfilling their responsibilities and respecting the internal procedures. In this regard, the greatest impact has the following programs (Garstea, 
2002): human resources policy, training, and professional development program and remuneration program.

The workplace satisfaction of the employee results in a high level of customer service. Very often, the positive opinion about the bank can be created by a good approach to the client by a cash-desk operator. Any worker, which is dealing directly with the client plays the role of "ambassador" of the bank, and on his actions and behavior depends the customer satisfaction, potential loyalty, and readiness to recommend further this bank to other people. His approach to the client affects directly and essentially the whole activity of the bank. Therefore, the personnel is the first and the most important factor in creating a positive image of the bank (Rogacheva, 2004).

Undiscernible image is the last stage to go through. The managers should understand that the bank image is a totality of socio-economic and organizational relationships, oriented towards the creation bank's "face", which is aligned with the demand of consumers and the general public values (Reshetikova, 2009). Image is a multifunctional, multilayered, and multicomponent communicational phenomenon (Gorchakova, 2005). In such a way, the image's impact is realized on both conscious and unconscious layers. The unconscious layer includes inner intentions, motives, interests; social, moral, and spiritual rules; individuality, emotional experience, and memories. The image's signals can be, therefore, strong and weak, obvious and implicit, visible and invisible, influencing the mind or affecting the feelings. The second one is defining the communication of the image. Thus, the psychological indirect signals have the greatest impact on the unconsciousness of the people, contributing to the improvement of the bank's image. The conductors of the unconscious signals are emotions and feelings, and the bases of emotions are perceptions and associative representations.

An essential feature of the bank's image is the ability to manage and determine the behavior and decisions of the recipients. In this regard, the image can be the instrument of manipulation, necessary to affect every recipient, to achieve the desired goal, or to stimulate the desired behavior. Thus, the image is created by both intentional and unintentional actions of the bank. And the unintentional play greater importance, as they are not planned and reveal the real state of things. Also, it should be considered the fact that the information linked to image building can be perceived consciously and unconsciously, purely based on feelings. And many people trust more their feelings than their analytics or mind, and the bank specialists in image building should use appropriately this fact.

As an important factor in building a positive bank image are also good performances and achievement of the set targets and goals, aligned with the bank strategy and corporate culture. The successful and correct day-to-day activity of the bank for a long time will result in a good image of the bank. It is recommended also to create permanently active crisis groups, which will analyze the potential scenarios of the development of a negative bank image and will elaborate on the appropriate methodologies to overcome such situations.

\section{CONCLUSIONS}

Bank image assesses qualitatively the opinion of the general public about the bank's activity. It is also the mean of communication with social mass consciousness, a way to transfer the information from the bank to the public, to achieve the goals of the former. A positive image results in many considerable advantages for a bank, such as capturing the attention of potential clients, partners, investors and workers, reduction of the expenses for advertising, and an increase in the bank's revenues and its competitive power.

The assessment of bank image differs from one group of interest to another. It determines the division of the aggregate bank image into the following elements: business image, social image, the image in the financial sector, image made by clients, by the government, by the international public, internal image, and the image of the bank subsidiary. Therefore, the formation and management of the bank image is a complex of activities, which include: communication of the corporate identity using different marketing techniques, correct management of the bank, especially related to risks and prudential norms, qualitative banking products, high level of customer service and implication in social programs. 
Improvement of the bank image contains the following steps: evaluation of the current image, especially of its weak points; reviewing the principles, values, and norms on which the bank's activity is based and, if necessary, re-formulating the bank's philosophy; checking the consistency between the bank's mission, objectives and longterm strategy; improving the external image elements, such as corporate identity, product quality, advertising, social activity, investor relations and media; improving the internal image by improving the general human resources policy, in particular, the training and professional development programs and the remuneration system; and developing the insensitive banking image by establishing deeply subconscious links between the bank's image and the emotions and values of the general public. The bank should also do its best to ensure its stability, durability, profitability, and trustworthiness, which impacts positively the bank image.

The image stirs up the public's trust in the bank's possibilities and responsibilities. An important point to be mentioned here is that the bank should be aware to create its image based on its real possibilities, without impossible promises. Otherwise, this dissonance will result in a negative image for the bank, due to asymmetry between the bank's supply and customers' demand and, also, not fulfillment of the promises and expectations, communicated previously through the bank's image.

\section{WORKS CITED}

Akulich, M. (2013). Imidzh torgovo-roznichnoy kompanii s uchetom segmentatsii i pozitsionirovaniya. Marketing: idei i tekhnologii(2), 55-61.

Burtseva, T., \& Mironova, N. (2008). Issledovaniye korporativnogo imidzha. Marketing(2), 24-35.

Bushuyeva, L., \& Frolova, I. (2015). Kontseptsiya i metodika issledovaniya korporativnogo imidzha. Marketing $v$ Rossii i za rubezhom, (4), 31-40. ISSN 1028-5849.

BCBS. (2015). Corporate governance principles for banks. Basel: Bank for International Settlements: https://www.bis.org/bcbs/publ/d328.pdf

Dell'atti, S., \& Trotta, A. (2016). Managing Reputation in the Banking Industry: Theory and Practice. Switzerland: Springer International Publishing Switzerland. 186 p. ISBN 978-3-319-28256-5.

Garştea, S. (2002). Strategii si tactici de cercetare a imaginii organizatiei. Annals of ATIC. Vol. II (III), 130-139. ISBN 9975-941-98-2.

Gorchakova, V. (2005). Vnutrenniy obraz ekspress-metodika glubinnogo imidzhirovaniya. Upravleniye personalom, (20), 64-70. ISBN 5-95630-007-8.

Nitu, I. (2000). Managementul riscului bancar. Bucuresti: Bucuresti Expert, 288 p. ISBN 973-8177-06-2.

Reshetikova, I. (2009). Ponyatiya "imidzh" i "reputatsiya" v kontekste sovremennykh ekonomicheskikh protsessov. Predprinimatel'stvo, (8), 153-156. ISSN 0869-7051.

Rid, S. (2008). Effektivno li vy podderzhivayete svoy imidzh?. Marketing, (6), 86-90. ISSN-0869-3722.

Rogacheva, M. (2004). Imidzh-sostavlyayushchaya uspekha rukovoditelya i organizatsii. Upravleniye personalom, (17), 60-62. ISBN 5-95630-007-8.

Rogaleva, N. (2007). Sovremennaya kontseptsiya imidzha organizatsii. Upravleniye personalom, (2), 42-45. ISBN 5-95630-007-8.

Smirnova, YU. (2009). Sravnitel'nyy analiz podkhodov k sravneniyu ponyatiy imidzh i reputatsiya. Marketing, (3), 40-57. ISSN-0869-3722.

Solcan, M. (2003). Conceptul de imagine a firmei. Economie si sociologie, (3), 95-99. ISSN 0236-3070. 
Received for publication:

Revision received:

29.05.2020

Accepted for publication:

\section{How to cite this article?}

Style - APA Sixth Edition:

Ciobu, S., Iordachi, V., \& Efimenco, O. (2020, July 15). The bank's image: Formation and ways of improvement. (Z. Cekerevac, Ed.) MEST Journal, 8(2), 78-88. doi:10.12709/mest.08.08.02.08

Style - Chicago Sixteenth Edition:

Ciobu, Stela, Victoria lordachi, and Olesea Efimenco. 2020. "The bank's image: Formation and ways of improvement." Edited by Zoran Cekerevac. MEST Journal (MESTE) 8 (2): 78-88. doi:10.12709/mest.08.08.02.08.

Style - GOST Name Sort:

Ciobu Stela, Iordachi Victoria and Efimenco Olesea The bank's image: Formation and ways of improvement [Journal] // MEST Journal / ed. Cekerevac Zoran. - Belgrade - Toronto : MESTE, July 15, 2020. - 2 : Vol. 8. - pp. 78-88.

Style - Harvard Anglia:

Ciobu, S., lordachi, V. \& Efimenco, O., 2020. The bank's image: Formation and ways of improvement. MEST Journal, 15 July, 8(2), pp. 78-88.

Style - ISO 690 Numerical Reference:

The bank's image: Formation and ways of improvement. Ciobu, Stela, Iordachi, Victoria and Efimenco, Olesea. [ed.] Zoran Cekerevac. 2, Belgrade - Toronto : MESTE, July 15, 2020, MEST Journal, Vol. 8, pp. 78-88. 